\title{
CULTURE MEDIUM MODULATES THE BEHAVIOUR OF HUMAN DENTAL PULP- DERIVED CELLS: TECHNICAL NOTE
}

\author{
S Lopez-Cazaux $^{1}$, G Bluteau ${ }^{1}$, D Magne $^{1}$, B Lieubeau ${ }^{2}$, J Guicheux $^{1 *}$ and B Alliot-Licht ${ }^{1}$
}

${ }^{1}$ INSERM EM 9903, Research Center on Materials with Biological Interest, School of Dental Surgery, 1 Place Alexis Ricordeau, 44042 Nantes cedex 1, France; ${ }^{2}$ IECM/UMR INRA 707, National Veterinary School, Atlanpole, la Chantrerie, BP 40706, 44307 Nantes cedex 3, France

\begin{abstract}
In vitro approaches have extensively been developed to study reparative dentinogenesis. While dental pulp is a source of unidentified progenitors able to differentiate into odontoblast-like cells, we investigated the effect of two media; MEM (1.8mM Ca and 1mM Pi) and RPMI 1640 $(0.8 \mathrm{mM} \mathrm{Ca}$ and $5 \mathrm{mM} \mathrm{Pi})$ on the behaviour of human dental pulp cells. Our data indicate that MEM significantly increased cell proliferation and markedly enhanced the proportion of $\alpha$-smooth muscle actin positive cells, which represent a putative source of progenitors able to give rise to odontoblast-like cells. In addition, MEM strongly stimulated alkaline phosphatase activity and was found to induce expression of transcripts encoding dentin sialophosphoprotein, an odontoblastic marker, without affecting that of parathyroid hormone/parathyroid hormone related protein-receptor and osteonectin. In conclusion, these observations demonstrate that not only proliferation but also differentiation into odontoblast-like cells was induced by rich calcium and poor phosphate medium (MEM) as compared to RPMI 1640. This study provides important data for the determination of the optimal culture conditions allowing odontoblast-like differentiation in human pulp cell culture.
\end{abstract}

Key Words: Dental pulp, Smooth muscle actin, Odontoblast-like cell differentiation, Cell culture

\author{
*Address for correspondence: \\ Dr Jerome Guicheux, Ph.D. \\ INSERM EM 9903, \\ Research Center on Materials with Biological Interest, \\ School of Dental Surgery, \\ 1 Place Alexis Ricordeau, \\ 44042 Nantes cedex 1, \\ France
}

Telephone (office) : +33(0)240412919

Telephone (secretary) : +33(0)240412916

Fax : +33(0)240083712

E-mail: jerome.guicheux@nantes.inserm.fr

\section{Introduction}

Dental pulp is a loose connective tissue that provides dentinogenic, nutritive, sensory, and defensive functions to the tooth (Tziafas et al., 2000). Dental diseases and injuries require replacement of the affected dental tissue. Traditional therapies with calcium hydroxide as a pulpcapping agent are successfully used to induce a reparative dentinogenic response (Goldberg and Smith, 2004). However, the current rapid progression in stem cell research has enhanced our knowledge of dental tissue regeneration and the major goal of dental research today is the development of biological approaches to promote this regeneration of dental tissues (Krebsbach and Robey, 2002; Seo et al., 2004; Zhang et al., 2005). In this context, culture of pulp cells appears as a promising tool to ensure the dental tissue regeneration (Bohl et al., 1998; Mitsiadis and Rahiotis, 2004). In culture, dental pulp cells are able to synthesize a specific matrix resembling dentin (Kasugai et al., 1993; Panagakos, 1998; Shiba et al., 1998; Onishi et al., 1999; About et al., 2000; Couble et al., 2000; Zhang et al., 2005). These cells are usually cultured in Eagle's basal medium, MEM, $\alpha$-MEM or D-MEM and the supplementation with $\beta$-glycerophosphate or dexamethasone is a prerequisite to observe odontoblastlike differentiation, nodule formation and mineralization. However, we recently described a model of human pulp cells cultured in RPMI 1640 in which the formation of mineralized nodules was observed without supplementation (Alliot-Licht et al., 2001). The progenitor cells capable of commitment into odontoblast-like cells that produce reparative dentine after injury as well as the cells that differentiate in odontoblast-like in culture are not yet identified. It is suggested that odontoblast-like progenitors derive from a perivascular niche within dental pulp (Shi and Gronthos, 2003) and recently, Tecles and co-authors clearly demonstrated that perivascular progenitor/stem cells can proliferate in response to dentin injury (Tecles et al., 2005). In human as well as in porcine dental pulp cultures, $\alpha$-smooth muscle actin-positive $(\mathrm{SMA}+)$ cells, identified as vascular-derived pericytes, were observed (Gronthos et al., 2000; Alliot-Licht et al., 2001; Brock et al., 2002; Shi and Gronthos, 2003). However, at the moment no information is available on the potential effect of medium on the expression of SMA in dental pulp cultures. RPMI 1640 exhibit different characteristics compared with MEM in which human dental pulp cells are usually cultured. RPMI 1640 contains a higher concentration in phosphate $(5 \mathrm{mM})$ and a lower concentration in calcium $(0.8 \mathrm{mM})$ than MEM a less nutrient-rich medium containing $1.8 \mathrm{mM}$ of calcium and 
$1 \mathrm{mM}$ of phosphate. In order to determine the culture conditions, which favour the recruitment, growth and differentiation of odontoblast-like progenitors, we sought to compare MEM and RPMI 1640 media that mainly differ by their ionic concentrations. This set of experiments underlines the importance of the experimental conditions and gains new insight in the behaviour of human dental pulp cells in culture.

\section{Materials and Methods}

\section{Materials}

Cell culture plasticware was purchased from Falcon (Becton-Dickinson, Franklin Lakes, NJ) and CorningCostar (D. Dutscher, Brumath, France). RPMI 1640, MEM, fetal calf serum (FCS), glutamine, antibiotics, trypsin/ ethylene-diamine tetraacetic acid (EDTA), bovine serum albumin (BSA), Trizol ${ }^{\circledR}$ reagent, DNase I and Taq DNA polymerase were obtained from Invitrogen (CergyPontoise, France). Avian myeloblastosis virus-reverse transcriptase (AMV-RT), random hexamers and recombinant ribonuclease inhibitor were purchased from Promega (Charbonnieres les bains, France). All other chemicals were from standard laboratory suppliers and of the highest purity available.

\section{Cells isolation and culture}

Human pulp cells were isolated and cultured as previously reported in details (Alliot-Licht et al., 2001). Briefly, human non-erupted third molars were extracted at the root development stage for clinical reasons, under general anaesthesia from healthy young people (14 to 25 years old) who gave their informed consent. The teeth were immediately cracked opened and the coronal pulp tissue was removed, minced into explants $\left(<1 \mathrm{~mm}^{3}\right)$ and placed in wells containing MEM or RPMI 1640 medium supplemented with $1 \%$ glutamine, penicillin/streptomycin (100 IU/ml-100 $\mu \mathrm{g} / \mathrm{ml})$, amphotericin-B $(10 \mu \mathrm{g} / \mathrm{ml})$ and $10 \% \mathrm{FCS}$ in a humidified atmosphere of $95 \%$ air and $5 \%$ $\mathrm{CO}_{2}$ at $37^{\circ} \mathrm{C}$. The standard medium was removed every two days. After one month, and then every 15 days, cells were collected by trypsinization and seeded at a density of $2 \times 10^{4}$ cells $/ \mathrm{cm}^{2}$ in complete medium (RPMI 1640 or MEM). For all sets of experiment, cells were used at the third passage. Data presented herein are representative of experiments with pulp from 9 different donors.

\section{Cell proliferation}

The effect of medium on the proliferation of human dental pulp cells was monitored by quantifying DNA synthesis through the incorporation of $\left[{ }^{3} \mathrm{H}\right]$ thymidine. Cells were seeded at 30,000 cells per well (24-well plates) and cultured in complete MEM or RPMI 1640 for the indicated times. Four hours prior to assaying, half of the medium was replaced by fresh medium containing $\left[{ }^{3} \mathrm{H}\right]$ thymidine $(1 \mu \mathrm{Ci} / \mathrm{ml})$ (APB, Saclay, France). After rinsing with PBS, cells were fixed for 15 minutes in $95 \%$ methanol. Sample were then dehydrated for 5 minutes at $37^{\circ} \mathrm{C}$ and incubated for one hour in $1 \mathrm{ml}$ of $\mathrm{NaOH}(0.1 \mathrm{~N})$. Radioactivity uptake was finally counted in a $\beta$-scintillation counter (Beckman,
LS 6 000SC). In order to provide an equivalent ratio of proliferation stimulating factors for each time of the experiment, half of the medium was changed in all other wells. Cell counts were performed after trypsinization with a haemocytometer using the trypan blue exclusion method. Results of cell proliferation were finally expressed as cpm per 1000 cells.

\section{Immunofluorescent labeling and flow cytometric analysis}

On day 4 after being seeded on cover glasses, cells were washed twice with PBS, fixed in $4 \%$ paraformaldehyde solution for $1 \mathrm{~h}$ at $4^{\circ} \mathrm{C}$ and washed for $20 \mathrm{~min}$ in washing buffer (PBS containing 3\% BSA). Cells were then incubated for 15 minutes in PBS containing $0.1 \%$ Triton $\mathrm{X}-100$ to permeabilize the cell membranes, and for a further $30 \mathrm{~min}$ at $37^{\circ} \mathrm{C}$ with the monoclonal anti-SMA antibody (mouse $\mathrm{IgG}_{2 \mathrm{a}}$ ) (Sigma). After rinsing with PBS, cells were incubated for $1 \mathrm{~h}$ at $37^{\circ} \mathrm{C}$ with an appropriate FITCconjugated goat anti-mouse IgG antibody (Sigma) and washed extensively with PBS. Negative controls were processed in the same way except that the first antibody was permuted with an isotype-matched negative control antibody $\operatorname{IgG}_{2 \mathrm{a}}$ (Sigma). The cover glasses were finally examined under a fluorescent-light microscope (Olympus BX60).

Flow cytometric analysis of SMA expression was carried out on human pulp cells seeded at a density of $10^{6}$ cells in $75 \mathrm{~cm}^{2}$ flasks and cultured in complete MEM or RPMI 1640, for 14 days. Cells were released using trypsin/ EDTA, washed in PBS and counted. $5 \times 10^{5}$ cells were aliquoted and fixed with paraformaldehyde (4\%) for 30 minutes. Cell membranes were permeabilized with triton X-100 $(0.025 \%)$ for 15 minutes and then rinsed twice with PBS. After blocking with human AB serum (Blood Transfusion Center, University Hospital, Nantes, France) for 15 minutes, cells were incubated consecutively with the same first and second antibodies as those used for immunocytochemistry. Finally, cells were washed twice in PBS on ice and resuspended in $100 \mu 1$ of paraformaldehyde (4\%). Analyses of fluorescent cells based on the reading of 5,000 events were performed with a FACScalibur using Cell-Quest software program (Beckton Dickinson, San Diego, Ca). Results were expressed as percentage of SMA positive cells in a typical histogram profile. The regions were set to the reactivity levels obtained with the isotype-matched negative control antibody.

\section{Alkaline phosphatase activity (ALP)}

Cells were seeded in 6-well plates at a density of $10^{5}$ cells per well and cultured in complete MEM or RPMI 1640. After 14 days in culture, cell layer was rinsed with PBS, scraped into $1 \mathrm{ml}$ of buffer ( $10 \mathrm{mM}$ Tris- $\mathrm{HCl}, 5 \mathrm{mM} \mathrm{MgSO}_{4}$, $0.1 \%$ Triton $\left.\mathrm{X} 100,0.1 \% \mathrm{NaNO}_{3}\right)$, frozen $\left(-20^{\circ} \mathrm{C}\right)$ and thawed 3 times, sonicated for 5 minutes to disrupt cell membranes and centrifuged $(4,000 \mathrm{~g})$ at $4^{\circ} \mathrm{C}$ for 15 minutes. ALP activity was determined by the hydrolysis of $p$ nitrophenyl phosphate in 2-amino-2-methyl-1-propanol buffer $(\mathrm{pH} 10.4)$ at $37^{\circ} \mathrm{C}$ for 30 minutes. Absorbance at $405 \mathrm{~nm}$ was measured with a spectrophotometer (Bio-Rad 
RPMI 1640

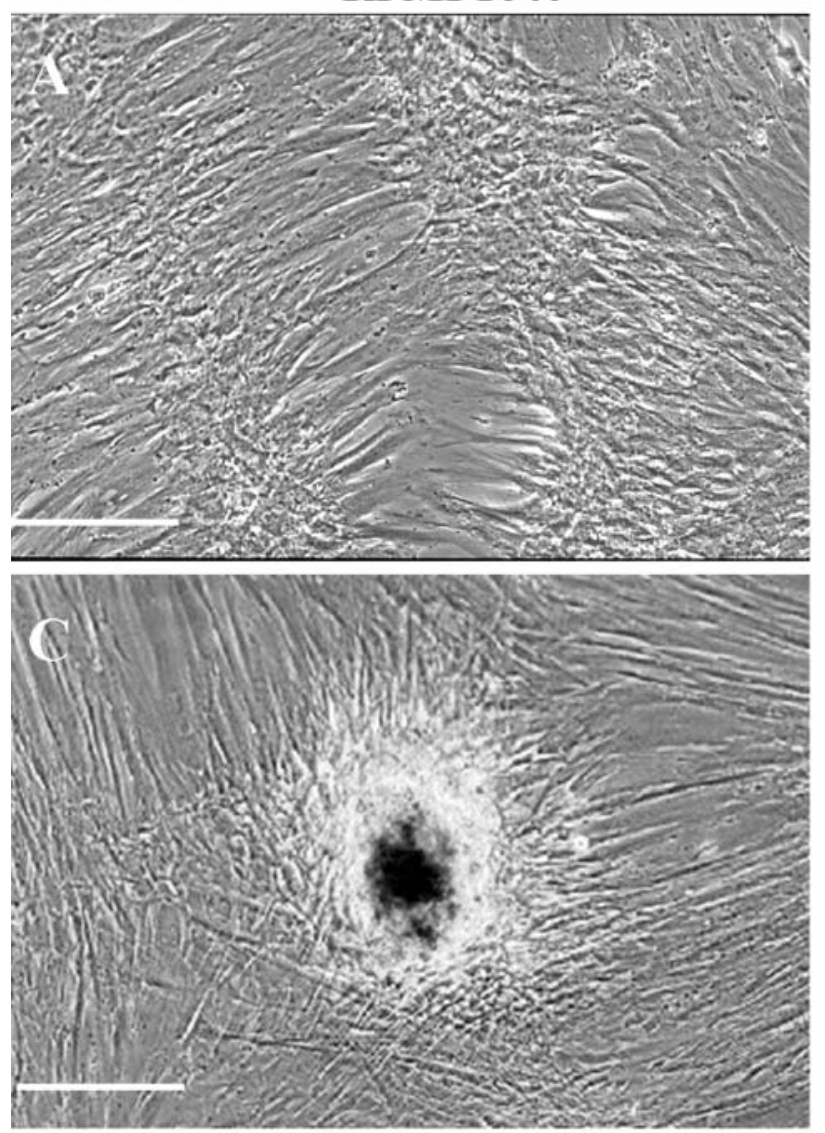

MEM
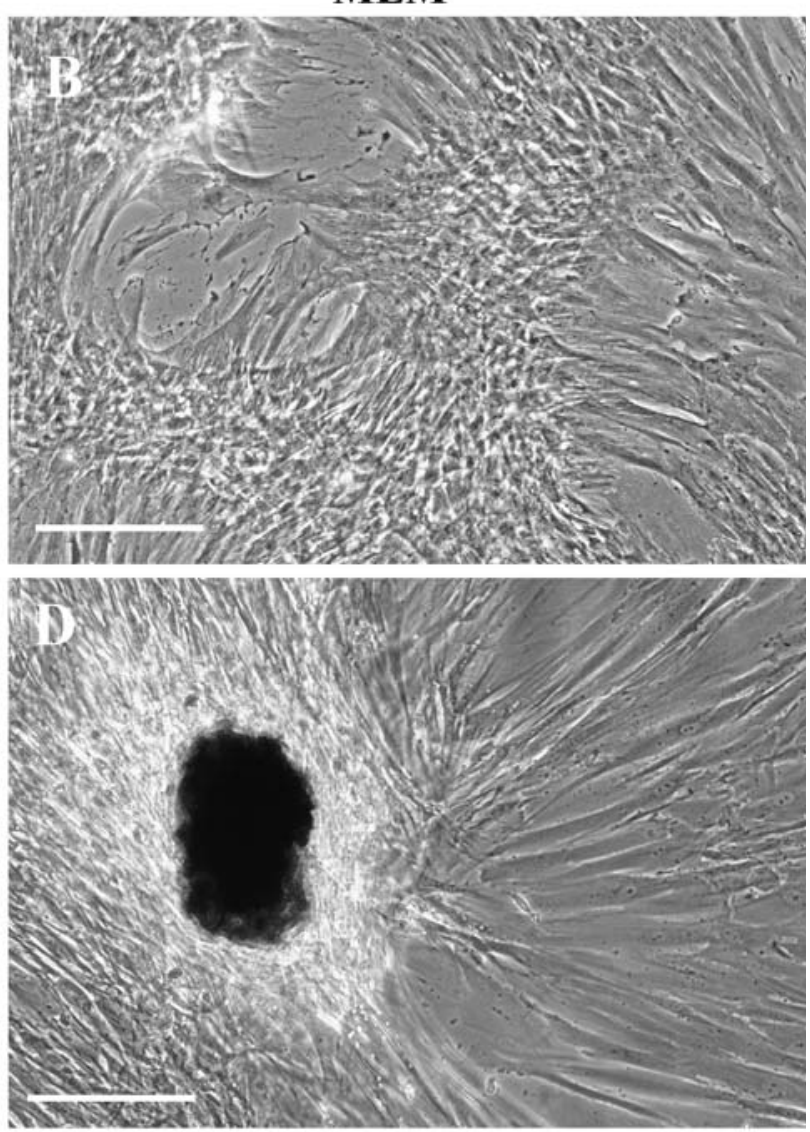

Figure1: Morphology of human dental pulp cells maintained in RPMI 1640 (A, C) or MEM (B, D) for 20 days (A, B) and 30 days (C, D) as described in Materials and Methods. Standard phase contrast photomicrographs illustrate the various cellular features, i.e. cell retraction with a hill-and-valley organization $(\mathrm{A}, \mathrm{B})$ and multicellular nodules $(\mathrm{C}, \mathrm{D})$. Bar $=100 \mu \mathrm{m}$.

3550 microplate Reader).

ALP activity was corrected for the total protein content (determined by the Bradford method using BSA as a standard) and was expressed as nMoles of paranitrophenol/ $\mathrm{min} / \mathrm{mg}$ of protein.

\section{Total RNA isolation}

The expression of various dentin and bone related transcripts were assessed by reverse transcriptionpolymerase chain reaction (RT-PCR). Total RNA was extracted from human pulp cells seeded in $25 \mathrm{~cm}^{2}$ flasks. After 14 days in culture, media (MEM or RPMI 1640) were removed. The cell layers were rinsed with RNase free PBS and stored at $-80^{\circ} \mathrm{C}$. Total RNA was extracted using Trizol according to the manufacturer's instructions. Briefly, lysis of the cells in Trizol was followed by centrifugation at $12,000 \mathrm{~g}, 4^{\circ} \mathrm{C}$ for 15 minutes in the presence of chloroform. The upper aqueous phase was collected and the RNA was precipitated by addition of isopropanol and centrifugation at $12,000 \mathrm{~g}, 4^{\circ} \mathrm{C}$ for 10 minutes. RNA pellets were washed with cold $75 \%$ ethanol, dried, reconstituted with sterile water, and quantified by spectrometry.

\section{RT-PCR}

After DNase I digestion, RNA samples $(2 \mu \mathrm{g})$ were reverse transcribed using AMV-RT and random hexamers in a total volume of $30 \mu \mathrm{l}$. Template cDNAs $(2.5 \mu \mathrm{l})$ were then amplified in a typical PCR reaction: $2.5 \mu \mathrm{l}$ buffer $10 \mathrm{x}(20$ $\mathrm{mM}$ Tris- $\mathrm{HCl}(\mathrm{pH} \mathrm{8.4)}, 50 \mathrm{mM} \mathrm{KCl}), 1 \mu \mathrm{M}$ of the respective primers, $200 \mu \mathrm{M} d \mathrm{dTP}$ and 2.5 units of Taq DNA polymerase. RNA samples that had not been reversetranscribed were included to check for the absence of DNA contamination. Primers sequences for PTH/PTHrpreceptor (PTH/PTHrpR) (Stewart et al., 1999), osteonectin (ON) (Gronthos et al., 1999), dentin sialophosphoprotein (DSPP) (Papagerakis et al., 2002) and glyceraldehyde phosphate dehydrogenase (GAPDH) (Bluteau et al., 1999) and annealing temperatures are detailed in table 1. Amplifications were carried out in an Eppendorf master cycler (VWR, Brumath, France) under the following conditions: denaturation for 3 minutes at $95^{\circ} \mathrm{C}$ followed by cycles of 20 s denaturation at $94^{\circ} \mathrm{C}, 20 \mathrm{~s}$ annealing at the primer specific temperature and 10 s elongation at $72^{\circ} \mathrm{C}$.

\section{Statistical analysis}

Data are from one representative experiment out of three performed with similar results. Results are expressed as mean \pm SEM of triplicate determinations. Comparative studies of means were performed using one way analysis of variance followed by a post-hoc test (Fisher's projected least significant difference) with a statistical significance at $p<0.05$. 


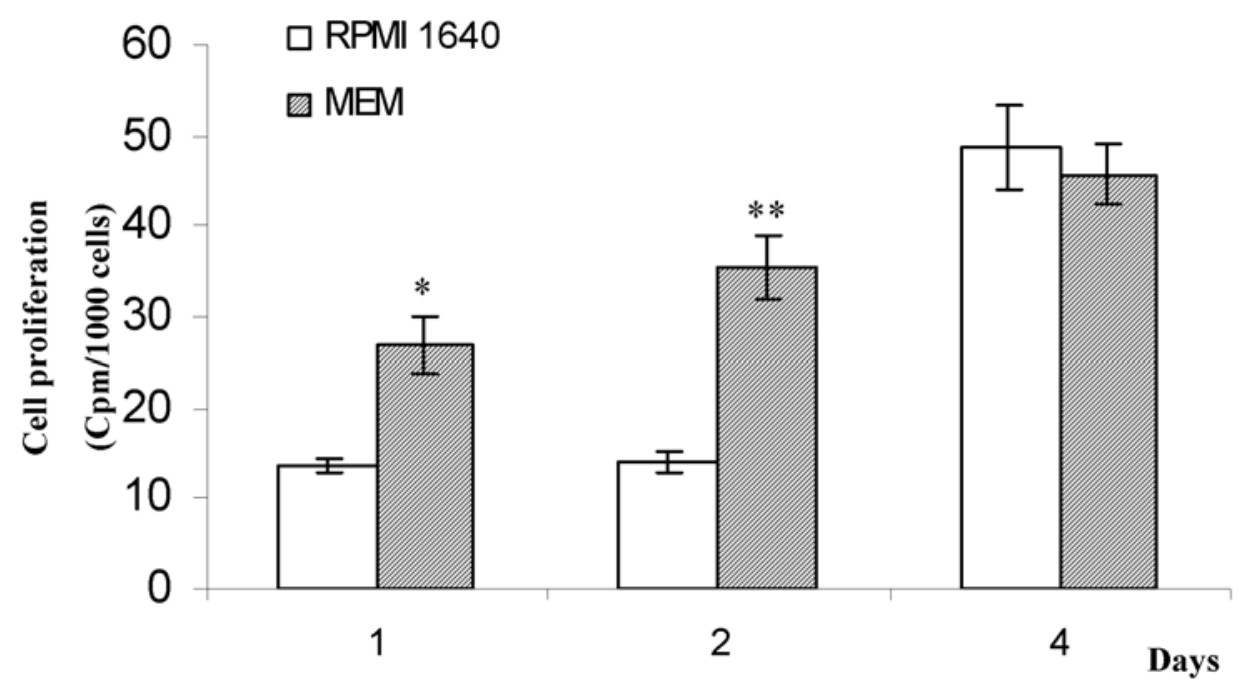

Figure.2: Effect of media on human dental pulp cell proliferation. Cells were cultured in RPMI 1640 or MEM for the indicated times and analyses were performed as described in Materials and Methods. $\left[{ }^{3} \mathrm{H}\right]$ thymidine incorporation have been standardized to cell numbers (cpm/1000 cells). Results are expressed as mean +/- SEM of triplicate determination. Results of one representative experiment are shown; ${ }_{*} p<0.05$ and ${ }_{* *} p<0.01$ as compared to RPMI 1640.

A
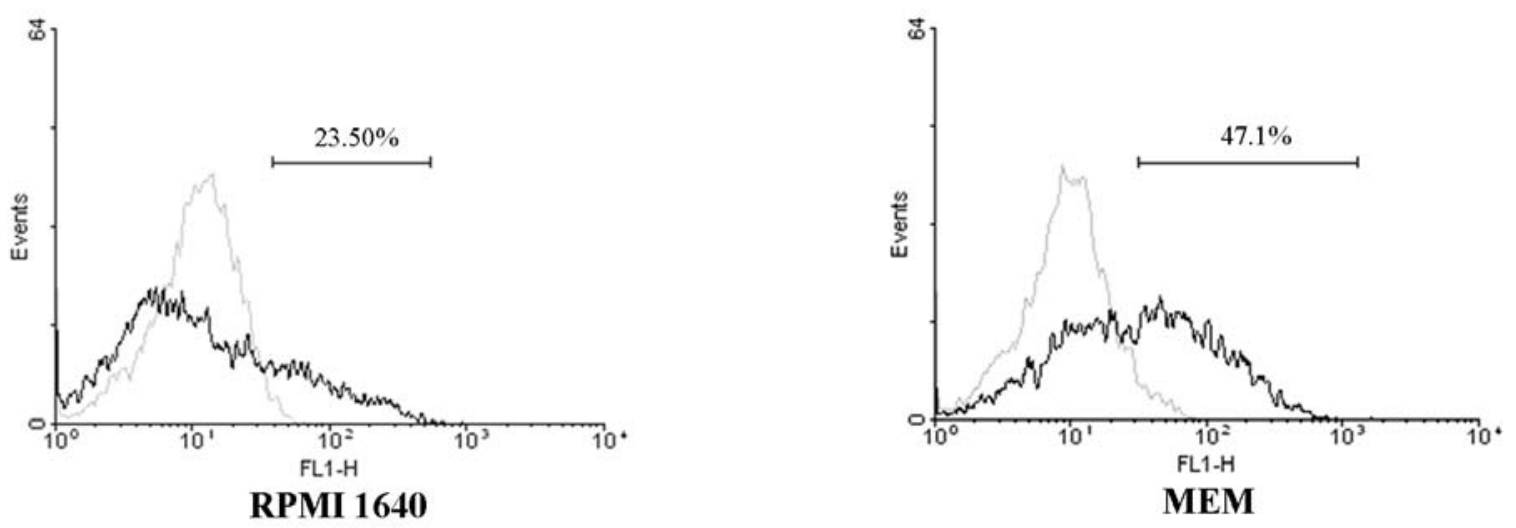

B

C

\begin{tabular}{cccc}
\hline & \multicolumn{3}{c}{ \%SMA positive cells } \\
\cline { 2 - 4 } Donor & RPMI 1640 & MEM & $\begin{array}{c}\text { Ratio MEM/RPMI } \\
\mathbf{1 6 4 0}\end{array}$ \\
\hline A & 20.1 & 50.3 & 2.5 \\
B & 28.08 & 73.35 & 2.6 \\
C & 14.11 & 20.32 & 1.44 \\
Mean & 20.76 & 47.99 & 2.18 \\
\hline
\end{tabular}

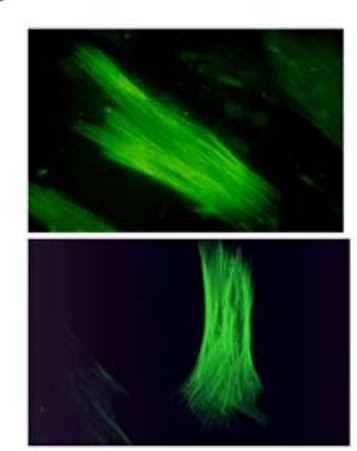

RMPI 1640

Figure 3: Effect of media on the number of SMA+ cells in human dental pulp cultures after 14 days in RPMI 1640 or MEM. (A) Flow cytometric data are shown as typical histograms of fluorescence intensity following labeling of cells with SMA (dark line) or an isotype matched control antibody (gray line). The bars defining the SMA + cells were set on each histogram. The percentage of SMA-labeled cells is given in each condition. Results from one representative experiment are shown. FL1-H = fluorescence intensity. (B) Quantitative analysis of SMA positive cells. Data obtained with three different donors are presented. (C) a-smooth muscle actin (SMA) feature in human dental pulp cells. Cells were cultured for 4 days in RPMI 1640 or MEM prior to immunostaining as described in Materials and Methods. $\mathrm{Bar}=25 \mu \mathrm{m}$. 
A

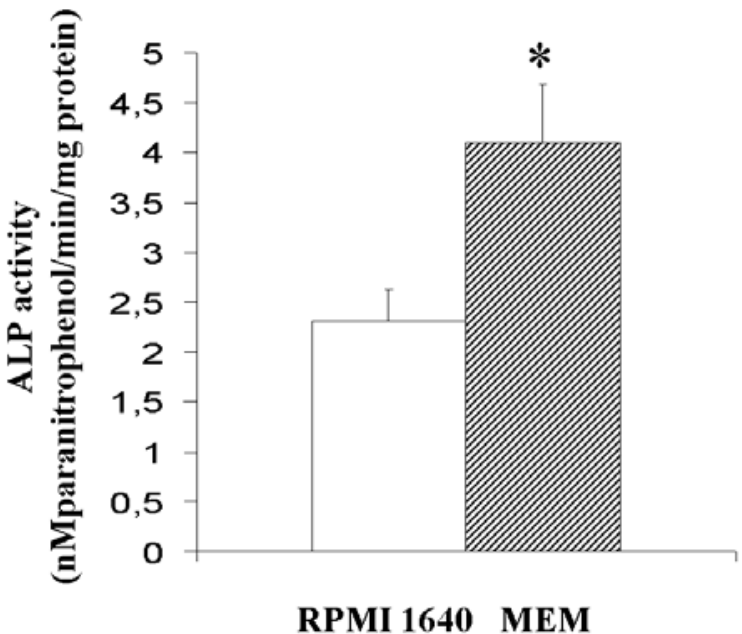

B

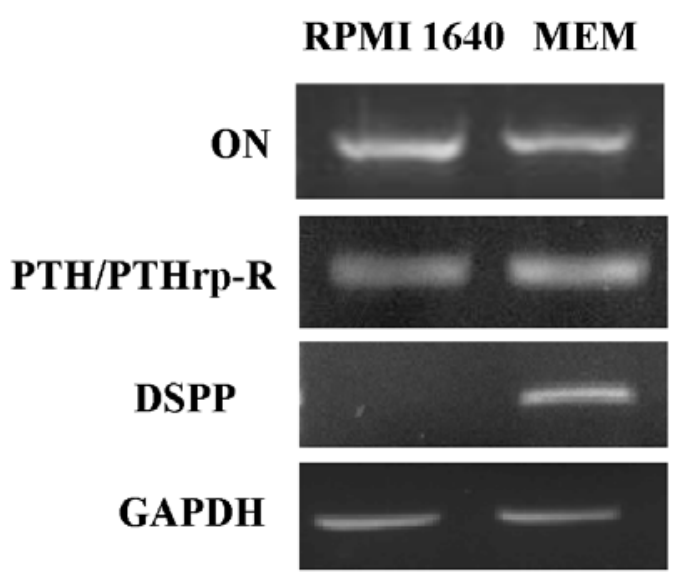

Figure 4: Effect of media on ALP activity and expression of related transcripts in human dental pulp cells. A: ALP activity. Cells were cultured with RPMI 1640 or MEM for 14 days as described in Materials and Methods. Experiments were done in triplicate and results are expressed as mean $+/$ - SEM $(* p<0.05$ as compared to RPMI 1640). B: Expression of parathyroid hormone/parathyroid hormone-related protein-receptor (PTH/PTHrp-R), osteonectin (ON), and dentin sialophosphoprotein (DSPP) transcripts in human dental pulp cells. Cells were cultured for 14 days with RPMI 1640 or MEM, prior to RT-PCR analysis as described in Materials and Methods. A representative agarose gel is shown.

\section{Results}

\section{Human pulp cells in culture}

Cells growing in both media (MEM and RPMI 1640) presented a similar morphology. Cell retractions forming distinct hill-and-valley-type of morphology (Fig. 1A, B) and multicellular foci or nodules (Fig. 1C, D) were observed. This cellular organization was previously described in cultures of microvascular pericytes (Proudfoot et al., 1998).

\section{Effect of media on cell proliferation}

Results concerning the rate of $\left[{ }^{3} \mathrm{H}\right]$ thymidine incorporation in human pulp cells cultured with MEM or RPMI 1640 are shown in figure 2. Thymidine incorporation was significantly higher in MEM than in RPMI 1640 after one and two days in culture, i.e. 2 and 2.5-fold increase, respectively.

Effect of media on the percentage of SMA+ cells The SMA+ cells are considered as a possible source of odontoblast-like cells (Miura et al., 2003; Shi and Gronthos, 2003). To investigate the effects of media on this pericyte marker, we assessed the number of SMA+ cells in our two culture conditions by flow cytometry. A typical histogram of one representative donor is shown in Fig 3A. Values obtained from three donors are presented in Fig 3B. For statistical analysis, values obtained with RPMI 1640 were standardized to $100 \%$ and compared with respective MEM conditions. Our results indicate that MEM induced a significant 2 -fold increase $(p<0.05)$ in the percentage of SMA+ cells compared to RPMI 1640 (Fig. 3B). Immunofluorescent staining confirmed the presence of SMA+ cells when human dental pulp cells were cultured in MEM as well as in RPMI 1640 (Fig. 3C).

\section{Effect of media on cell differentiation}

The increase in ALP activity is a common feature of osteoblastic and odontoblastic differentiation. ALP activity in human dental pulp cells was markedly stimulated by MEM. A two-fold increase was observed after 14 days as compared to culture in RPMI 1640 (Fig. 4A).

To strengthen the above data, we analyzed the effects of media on the steady-state level of mRNA encoding various osteo/odontoblastic markers (PTH/PTHrpreceptor, ON, and DSPP) (Fig. 4B). Human dental pulp cells were found to express mRNAs encoding PTH/PTHrp receptor and $\mathrm{ON}$ in the two culture conditions. While expression of these two markers remained unchanged, we found that MEM induced expression of DSPP (Fig. 4B). This result strongly suggests that MEM promoted differentiation of at least one unidentified subpopulation of dental pulp cells towards an odontoblastic phenotype. GAPDH was used as an internal control and remained unchanged.

\section{Discussion}

Engineering oral tissues using dental pulp cells is viewed as having promising clinical potential and could provide an alternative to the traditional therapy (Bohl et al., 1998; Gronthos et al., 2000; Murray et al., 2002; Zhang et al., 2005). Indeed, dental pulp stem cells obtained from third molar or from exfoliated deciduous teeth were identified by their capacity to form clonogenic cell clusters (colonyforming units fibroblasts; CFU-F) and to differentiate into various cell types, including but not limited to osteoblasts/ 
odontoblasts, adipocytes and neural cells (Gronthos et al., 2000; Shi et al., 2001; Gronthos et al., 2002; Krebsbach and Robey, 2002; Miura et al., 2003). When dental pulp stem cells are mixed with calcium phosphate scaffolds and transplanted subcutaneously into immunocompromised mice, they formed dentin/pulp complex (Gronthos et al., 2002; Batouli et al., 2003; Miura et al., 2003). Rat dental pulp cell populations containing stem cells exhibit the ability to differentiate into odontoblast-like cells in cultured and Zhang and co-authors revealed that this odontogenic properties is not altered when cells are cultured on threedimensional calcium phosphate as well as titanium scaffold (Zhang et al., 2005). In this context, we aimed at determining which medium could favour growth and differentiation of odontoblast-like progenitors in human dental pulp cultures.

Because it was described that the medium can influence the cell population in cultures of bovine pulp cells (Nakashima, 1991), we firstly sought to investigate the effects of two different media (MEM and RPMI 1640) on cellular morphology and nodule formation. Interestingly, cells derived from human dental pulp exhibited comparable morphological features and nodules were observed in both media. In addition, based on the rate of ${ }^{3}[\mathrm{H}]$ thymidine incorporation, our results indicate that MEM is more potent in stimulating cell proliferation than RPMI 1640. One of the main differences between MEM and RPMI 1640 is their relative calcium and phosphate contents. In this range of ionic concentration, a recent study indicates that a gradual increase $(0-4 \mathrm{mM})$ in calcium concentration promotes osteoblastic cell proliferation (Maeno et al., 2005). In view of this above mentioned study, it is reasonable to speculate that the higher concentration of calcium in MEM could favour dental pulp cell proliferation. At all events, our results are in agreement with a comparative study dealing with the effects of various media on bovine dental pulp cells (Nakashima, 1991).

Dental pulp cultures containing stem cells were found to express CD146 a marker of smooth muscle cells, endothelial cells and pericytes, implying that these cells may have originated from a perivascular microenvironment (Miura et al., 2003; Shi and Gronthos, 2003). In addition, transplantation of CD146 positive specific population isolated from dental pulp stem cells into immunocompromised mice, allow the formation of dentin and pulp tissue (Shi and Gronthos, 2003). The finding of this study defines distinct primitive stem cell populations associated with the blood vessels of pulp tissue that express CD146 with preodontogenic potential (Shi and Gronthos, 2003). Interestingly, $85 \%$ of the isolated CD146 positive cells express a-smooth muscle actin (SMA) (Shi and Gronthos, 2003). The presence of SMA positive cells was previously described in porcine dental pulp cultures (Brock et al., 2002) and in dental human pulp cultures (Gronthos et al., 2000; Alliot-Licht et al., 2001; Alliot-Licht et al., 2005). While RPMI 1640 affects cell growth to a lesser extent than MEM, it has been successfully used for the culture of human pulp cells (Alliot-Licht et al., 2001). For that reason, we next explored the effects of media on the proportion of cells expressing SMA. As previously reported (Alliot-Licht et al., 2001; Alliot-Licht et al., 2005), we evidenced SMA+ cells in human pulp cultures with RPMI 1640. Moreover, the presence of SMA+ cells in cultures with MEM was not surprising because SMA+ cells were recently reported in human pulp cells cultured in $\alpha-$ MEM (Gronthos et al., 2000) and in porcine dental pulp cells cultured in DMEM F12 medium (Brock et al., 2002). Interestingly, in our model of human dental pulp culture that contains cells at various stages of differentiation (Alliot-Licht et al., 2005), our results demonstrated that a calcium-rich and phosphate-poor medium (MEM) supports recruitment and/or proliferation of SMA+ cells in human dental pulp cultures. This data therefore appears in agreement with previous reports, which showed that MEM could be successfully employed in culture of cells expressing smooth muscle cell markers (pericytes or calcifying vascular cells). Indeed, these cells routinely cultured in MEM spontaneously formed multicellular nodules that mineralized without exogenous factors (Schor et al., 1995; Proudfoot et al., 1998; Canfield et al., 2000). However, in order to explain the lower proportion of SMA+ cells in RPMI 1640 medium, we can hypothesize that the high phosphate concentration $(5 \mathrm{mM})$ had induced a phenotypic transition characterized by a loss of $\alpha$-smooth muscle actin as previously described in bovine aortic smooth muscle cells (Steitz et al., 2001).

To investigate whether media may affect cellular differentiation, we next assessed alkaline phosphatase activity. This enzyme is widely used as a marker of calcified tissue derived cells such as odontoblasts (Goseki et al., 1990; Onishi et al., 1999). Our results demonstrated that MEM induces a higher ALP activity compared to RPMI 1640. Because at day 14, the amount of total proteins was not different between both conditions (data not shown), the variation noted in ALP activity is likely to be related to the specific activity of this enzyme. The elevated concentration of calcium in MEM medium could be responsible for this enhancement of ALP activity. Although a previous study in bone cells evidenced an increase in ALP activity in a low-calcium environment (Yoshimura et al., 1996), an up-regulation of the numbers of ALPpositive colonies was recently reported with the gradual increase in calcium concentration $(0-4 \mathrm{mM})$ in osteoblastic cells (Maeno et al., 2005). In light of these diverging results, a specific study related to the effects of calcium and/or phosphate on human dental pulp cells is needed to gain new insights into the mechanism by which MEM favors proliferation and cellular differentiation in culture. Nevertheless, adding phosphate in MEM in the ratio which is present in RPMI 1640 and conversely, could induce a spontaneous mineral precipitation as previously described (Khouja et al., 1990).

To find out whether enhancement of ALP activity in MEM culture is related to the stimulation of osteoblastic or odontoblastic differentiation, we investigated the expression of genes coding for other markers of the osteoblastic or odontoblastic phenotype. In both media, RT-PCR analysis evidenced expression of cellular markers of osteo and/or odontoblastic lineage, namely, osteonectin and PTH/PTHrp-receptor. Our experiment evidenced that the steady state level of transcripts encoding the previously mentioned markers was not influenced by the medium. 
Although DSPP was described in bone and enamel (Qin et al., 2002), it remains one of the most widely used odontoblastic marker (D'Souza et al., 1997; Couble et al., 2000; Gronthos et al., 2000; Shi et al., 2001; Miura et al., 2003; Zhang et al., 2005). Interestingly, DSPP mRNA expression was observed in MEM culture whereas, like in our previous report (Alliot-Licht et al., 2005), the expression of DSPP was not detected when dental pulp cells were cultured in RPMI 1640. In light of these data, one can assume that MEM is able to promote odontoblastic differentiation of precursors present in human pulp cultures without an exogenous phosphate source or dexamethasone.

In conclusion, this study demonstrates that cell culture medium modulates human pulp cell behaviour. In view of our results and as compared to RPMI 1640, MEM has proved to be the more potent culture medium in terms of cellular proliferation, percentage of SMA+ cells and odontoblast-like differentiation. The main difference between these media is their calcium/phosphate contents. Consequently, because these ions are released during dentin injury or when calcium hydroxide is applied on pulp tissue (Kardos et al., 1998), it could be of interest to further investigate their specific effects on cells derived from human dental pulp.

\section{Acknowledgments}

Authors gratefully acknowledge Isabelle Barbieu for technical assistance, Paul Pilet for helpful suggestion, and Isabelle Brisson for critical reading of the manuscript. This work was supported by grants from "Institut Français pour la Recherche Odontologique" (B. Alliot-Licht) and INSERM EM 9903 (J. Guicheux).

\section{References}

About I, Bottero MJ, de Denato P, Camps J, Franquin JC, Mitsiadis TA (2000) Human dentin production in vitro. Exp Cell Res 258: 33-41.

Alliot-Licht B, Bluteau G, Magne D, Lopez-Cazaux S, Lieubeau B, Daculsi G, Guicheux J (2005) Dexamethasone stimulates differentiation of odontoblast-like cells in human dental pulp cultures. Cell Tissue Res 321: 391-400.

Alliot-Licht B, Hurtrel D, Gregoire M (2001) Characterization of alpha-smooth muscle actin positive cells in mineralized human dental pulp cultures. Arch Oral Biol 46: 221-228.

Batouli S, Miura M, Brahim J, Tsutsui TW, Fisher LW, Gronthos S, Robey PG, Shi S (2003) Comparison of Stemcell-mediated Osteogenesis and Dentinogenesis. J Dent Res 82: 976-981.

Bluteau G, Labourdette L, Ronziere M, Conrozier T, Mathieu P, Herbage D, Mallein-Gerin F (1999) Type X collagen in rabbit and human meniscus. Osteoarthritis Cartilage 7: 498-501.

Bohl KS, Shon J, Rutherford B, Mooney DJ (1998) Role of synthetic extracellular matrix in development of engineered dental pulp. J Biomater Sci Polym Ed 9: 749764.
Brock DP, Marty-Roix R, Spector M (2002) Alphasmooth-muscle actin in and contraction of porcine dental pulp cells. J Dent Res 81: 203-208.

Canfield AE, Doherty MJ, Wood AC, Farrington C, Ashton B, Begum N, Harvey B, Poole A, Grant ME, BootHandford RP (2000) Role of pericytes in vascular calcification: a review. Z Kardiol 89: 20-27.

Couble ML, Farges JC, Bleicher F, Perrat-Mabillon B, Boudeulle M, Magloire H (2000) Odontoblast differentiation of human dental pulp cells in explant cultures. Calcif Tissue Int 66: 129-138.

D'Souza RN, Cavender A, Sunavala G, Alvarez J, Ohshima T, Kulkarni AB, MacDougall M (1997) Gene expression patterns of murine dentin matrix protein 1 (Dmp1) and dentin sialophosphoprotein (DSPP) suggest distinct developmental functions in vivo. $\mathrm{J}$ Bone Miner Res 12: 2040-2049.

Goldberg M, Smith AJ (2004) Cells and extracellular matrices of dentin and pulp/ a biological basis for repair and tissue engineering. Crit Rev Oral Biol Med 15: 13-27.

Goseki M, Oida S, Nifuji A, Sasaki S (1990) Properties of alkaline phosphatase of the human dental pulp. J Dent Res 69: 909-912.

Gronthos S, Brahim J, Li W, Fisher LW, Cherman N, Boyde A, DenBesten P, Robey PG, Shi S (2002) Stem cell properties of human dental pulp stem cells. J Dent Res 81: 531-535.

Gronthos S, Mankani M, Brahim J, Robey PG, Shi S (2000) Postnatal human dental pulp stem cells (DPSCs) in vitro and in vivo. Proc Natl Acad Sci USA 97: 1362513630.

Gronthos S, Zannettino AC, Graves SE, Ohta S, Hay SJ, Simmons PJ (1999) Differential cell surface expression of the STRO-1 and alkaline phosphatase antigens on discrete developmental stages in primary cultures of human bone cells. J Bone Miner Res 14: 47-56.

Kardos TB, Hunter AR, Hanlin SM, Kirk EE (1998) Odontoblast differentiation: a response to environmental calcium? Endod Dent Traumatol 14: 105-111.

Kasugai S, Shibata S, Suzuki S, Susami T, Ogura H (1993) Characterization of a system of mineralized-tissue formation by rat dental pulp cells in culture. Arch Oral Biol 38: 769-777.

Khouja HI, Bevington A, Kemp GJ, Russell RG (1990) Calcium and orthophosphate deposits in vitro do not imply osteoblast-mediated mineralization: mineralization by betaglycerophosphate in the absence of osteoblasts. Bone 11: $385-391$.

Krebsbach PH, Robey PG (2002) Dental and skeletal stem cells: potential cellular therapeutics for craniofacial regeneration. J Dent Educ 66: 766-773.

Maeno S, Niki Y, Matsumoto H, Morioka H, Yatabe T, Funayama A, Toyama Y, Taguchi T, Tanaka J (2005) The effect of calcium ion concentration on osteoblast viability, proliferation and differentiation in monolayer and 3D culture. Biomaterials 26: 4847-4855.

Mitsiadis TA, Rahiotis C (2004) Parallels between tooth development and repair: conserved molecular mechanisms following carious and dental injury. J Dent Res 83: 896902. 
Miura M, Gronthos S, Zhao M, Lu B, Fisher LW, Robey PG, Shi S (2003) SHED: stem cells from human exfoliated deciduous teeth. Proc Natl Acad Sci USA 100: 5807-5812.

Murray PE, Lumley PJ, Smith AJ (2002) Preserving the vital pulp in operative dentistry: 2. Guidelines for successful restoration of unexposed dentinal lesions. Dent Update 29: 127-134.

Nakashima M (1991) Establishment of primary cultures of pulp cells from bovine permanent incisors. Arch Oral Biol 36: 655-663.

Onishi T, Kinoshita S, Shintani S, Sobue S, Ooshima $\mathrm{T}$ (1999) Stimulation of proliferation and differentiation of dog dental pulp cells in serum-free culture medium by insulin-like growth factor. Arch Oral Biol 44: 361-371.

Panagakos FS (1998) Transformation and preliminary characterization of primary human pulp cells. J Endod 24: 171-175.

Papagerakis P, Berdal A, Mesbah M, Peuchmaur M, Malaval L, Nydegger J, Simmer J, Macdougall M (2002) Investigation of osteocalcin, osteonectin, and dentin sialophosphoprotein in developing human teeth. Bone 30: 377-385.

Proudfoot D, Skepper JN, Shanahan CM, Weissberg PL (1998) Calcification of human vascular cells in vitro is correlated with high levels of matrix Gla protein and low levels of osteopontin expression. Arterioscler Thromb Vasc Biol 18: 379-388.

Qin C, Brunn JC, Cadena E, Ridall A, Tsujigiwa H, Nagatsuka H, Nagai N, Butler WT (2002) The expression of dentin sialophosphoprotein gene in bone. J Dent Res 81: $392-394$.

Schor AM, Canfield AE, Sutton AB, Arciniegas E, Allen TD (1995) Pericyte differentiation. Clin Orthop 313: 81-91.

Seo BM, Miura M, Gronthos S, Bartold PM, Batouli S, Brahim J, Young M, Robey PG, Wang CY, Shi S (2004) Investigation of multipotent postnatal stem cells from human periodontal ligament. Lancet 364: 149-155.

Shi S, Gronthos S (2003) Perivascular niche of postnatal mesenchymal stem cells in human bone marrow and dental pulp. J Bone Miner Res 18: 696-704.

Shi S, Robey PG, Gronthos S (2001) Comparison of human dental pulp and bone marrow stromal stem cells by cDNA microarray analysis. Bone 29: 532-539.

Shiba H, Fujita T, Doi N, Nakamura S, Nakanishi K, Takemoto T, Hino T, Noshiro M, Kawamoto T, Kurihara H, Kato Y (1998) Differential effects of various growth factors and cytokines on the syntheses of DNA, type I collagen, laminin, fibronectin, osteonectin/secreted protein, acidic and rich in cysteine (SPARC), and alkaline phosphatase by human pulp cells in culture. J Cell Physiol 174: 194-205.

Steitz SA, Speer MY, Curinga G, Yang HY, Haynes P, Aebersold R, Schinke T, Karsenty G, Giachelli CM (2001) Smooth muscle cell phenotypic transition associated with calcification: upregulation of $\mathrm{Cbfa} 1$ and downregulation of smooth muscle lineage markers. Circ Res 89: 11471154 .
Stewart K, Walsh S, Screen J, Jefferiss CM, Chainey J, Jordan GR, Beresford JN (1999) Further characterization of cells expressing STRO-1 in cultures of adult human bone marrow stromal cells. J Bone Miner Res 14: 13451356.

Tecles O, Laurent P, Zygouritsas S, Burger AS, Camps J, Dejou J, About I (2005) Activation of human dental pulp progenitor/stem cells in response to odontoblast injury. Arch Oral Biol 50: 103-108.

Tziafas D, Smith AJ, Lesot H (2000) Designing new treatment strategies in vital pulp therapy. J Dent 28: 7792.

Yoshimura Y, Hisada Y, Suzuki K, Deyama Y, Matsumoto A (1996) Effect of a low-calcium environment on alkaline phosphatase activity in embryonic rat calvarial bone cells in culture. Arch Oral Biol 41: 41-45.

Zhang W, Walboomers XF, Wolke JG, Bian Z, Fan MW, Jansen JA (2005) Differentiation ability of rat postnatal dental pulp cells in vitro. Tissue Eng 11: 357-368.

\section{Discussion with Reviewers}

ROC Oreffo: Do these cells maintain an undifferentiated phenotype?

Authors: Yes, it is possible to maintain the human pulp cells in culture in an undifferentiated phenotype with essential basal medium. See Couble et al. (2000).

ROC Oreffo: What is the effect of acidose on dental pulp cells and exogenously added calcium?

Authors: During pulp capping process, the success of calcium hydroxide is generally attribute to the alkalinisation of medium surrounding the pulp healing but Kardos and co-authors reported the effect of calcium ions released by $\mathrm{Ca}(\mathrm{OH})_{2}$ capping agent. The role of ionic gradient for calcium ions in facilitating repair cannot be considered in isolation and it has been suggested that calcium ions are not necessary for repair process. Cells have been able to use an influx of calcium ions across the membrane for many cellular events (mitosis, secretion, contraction or regulation of gene expression). Calcium may be regarded as an intracellular messenger but through precise regulation of the free calcium ion concentration in the cytosol, cells have been able to utilize polyanions such as phosphate. For review see Kardos et al. (1998).

ROC Oreffo: Do the authors have many data on the uni or bipotentiality of these cells?

Authors: Human pulp cells obtained by enzymatic digestion and cultured in specific inductive medium can commit toward an osteoblastic, adipogenic or an neuronal phenotype (Gronthos et al., 2000; Gronthos et al., 2002; Shi and Gronthos, 2003). In addition, preliminary results in our lab led us to suppose that in our model of human dental pulp cells a differentiation process towards chondrocytes can be induced by a chondrogenic medium. These results evidence the plasticity of dental pulp cells in culture. 